\title{
Maturação e fecundação in vitro de ovócitos de caninos domésticos (Canisfamiliaris)*
}

\author{
BERENICE DE ÁVILA RODRIGUES
}

José Luiz Rodrigues (Orientador - UFRGS)

Banca: Rodrigo Costa Mattos (UFRGS), Mara Iolanda Batistela Rubin (UFSM), Lígia Pegoraro (EMBRAPA)

Este estudo foi realizado com os objetivos de 1) determinar a eficácia de duas temperaturas $\left(37^{0} \mathrm{C}\right.$ e $\left.39^{\circ} \mathrm{C}\right)$ e três intervalos de tempo (48, 72 e 96h) na maturação in vitro (MIV) de ovócitos caninos, 2) verificar o efeito de FSH, estradiol, somatotropina humana (hST), albumina sérica bovina (BSA), soro de vaca em estro (SVE) e soro de cadela em estro (SCE) na MIV de ovócitos caninos, 3) observar a influência da condição reprodutiva das doadoras de ovários sobre os índices de MIV, 4) verificar a habilidade para fecundação in vitro (FIV) e desenvolvimento embrionário in vitro de ovócitos coletados de fêmeas em diferentes estágios do ciclo estral. O meio de maturação usado foi TCM-199 com Hepes, SVE, gentamicina, bicarbonato de sódio, ácido pirúvico, estradiol, FSH e hCG. O meio de maturação era modificado de acordo com a proposta experimental. Os resultados do primeiro experimento não mostraram diferença no índice de meiose de ovócitos maturados à $37^{\circ} \mathrm{C}$ ou à $39^{\circ} \mathrm{C}$ em quaisquer dos intervalos testados. No segundo experimento, os índices mais elevados de retomada da meiose após 72 horas da MIV foram obtidos, quando TCM-199 era suplementado com BSA. Ovócitos maturados em TCM199 com SCE não se desenvolveram até o estádio de metáfase II (MII). No terceiro experimento, os resultados de maturação dos ovócitos não mostraram diferença na progressão do material nuclear até MII entre os ovócitos provenientes de cadelas em várias condições reprodutivas. No experimento de FIV, os ovócitos foram distribuídos em 3 grupos de acordo com o estágio do ciclo estral da doadora em folicular, anestro e luteal. Após maturação, os ovócitos eram fecundados e cultivados in vitro. O índice de ovócitos desenvolvendo-se em embriões foi de 10,1\%. O índice de clivagem foi similar nas fases reprodutivas. Foi verificada influência da fase folicular sobre o desenvolvimento de pronúcleos. Não foi estabelecida correlação entre a proporção de espermatozóides capacitados ou com reação acrossômica e formação pronuclear e/ou percentagem de clivagem. Concluiu-se que: a) ovócitos caninos podem ser maturados in vitro a $39^{\circ} \mathrm{C}$ e $37^{\circ} \mathrm{C}$. b) a adição de FSH, estradiol, hST, BSA, SVE e SCE ao meio TCM-199 não eleva os índices de maturação nuclear até MII de ovócitos caninos maturados in vitro. c) em cães, a seleção de ovócitos com base na coleta dentro de um estágio específico do ciclo estral não deve ser usada para prever índices de meiose ou habilidade para desenvolvimento embrionário in vitro. d) ovócitos caninos maturados, fecundados e cultivados in vitro podem se desenvolver a zigotos com até 8 células.

Descritores: canino, ovócito, in vitro, maturação, fecundação, clivagem, temperatura, ciclo estral.

\footnotetext{
* Tese de Doutorado n. 28 (Especialidade: Biotécnicas de Reprodução). 119f. Programa de Pós-graduação em Ciências Veterinárias da Faculdade de Veterinária - UFRGS, Porto Alegre/RS. CORRESPONDÊNCIA: B. A. Rodrigues [berenice@ portoweb.com.br].
} 


\title{
In vitro maturation and in vitro fecundation of canine oocytes (Canisfamiliaris)**
}

\author{
BERENICE DE ÁVILA RODRIGUES
}

José Luiz Rodrigues (Adviser - UFRGS)

Committee: Rodrigo Costa Mattos (UFRGS), Mara Iolanda Batistela Rubin (UFSM), Lígia Pegoraro (EMBRAPA)

This study was designed 1) to determine the effectiveness of two temperatures $\left(37^{\circ} \mathrm{C}\right.$ and $\left.39^{\circ} \mathrm{C}\right)$ and three in vitro maturation (IVM) time culture intervals (48, 72 and $96 \mathrm{~h}$ ) to produce nuclear mature dog oocytes, 2) to assess the effects of FSH, oestradiol, human somatotrophin (hST), bovine serum albumin (BSA), estrous cow serum (ECS), and estrous bitch serum (EBS) on oocyte nuclear maturation of dog oocytes, 3) to observe the influence of bitch reproductive status on in vitro oocyte maturation rates, 4) to verify the ability of in vitro matured oocytes recovered from females at different estrous cycle stages to be in vitro fertilized, and to examine their capacity to embryonic development in vitro. Basic medium was TCM-199 with Hepes, ECS, gentamicin, sodium bicarbonate, pyruvic acid, oestradiol, FSH and hCG. Maturation medium was modified following the beyond described experimental proposals. The results of the first experiment showed that there was no statistical difference in the rate of meiosis of oocytes matured at $37^{\circ} \mathrm{C}$ or at $39^{\circ} \mathrm{C}$ at any time point. In the second experiment, the highest rates of meiotic resumption after 72 hours of IVM were achieved when TCM-199 was added with BSA. Oocytes cultured in TCM-199 with EBS did not develop to the MII stage. In the third experiment, there was no difference in nuclear progression to MII among oocytes retrieved from bitches at various reproductive states. Our results indicate that in vitro nuclear maturation of dog oocytes is not influenced by reproductive status of the female at the moment of oocyte retrieval. In the IVF experiment, oocytes were distributed into 3 groups according the donor's estrous cycle stage in follicular, anestrus, and luteal phase. After maturation, oocytes were submitted to IVF and culture. Rate of oocytes developing into embryos was $10.1 \%$. Cleavage rate was similar among the reproductive categories. There was an effect of follicular phase on pronucleus development. There was no correlation between the proportion of capacitated or acrosome reacted spermatozoa and pronuclei formation and/or cleavage percentage. It was concluded that: a) canine oocytes can be in vitro matured at $39^{\circ} \mathrm{C}$ and $37^{\circ} \mathrm{C}$ temperatures. b) addition of FSH, oestradiol, hST, BSA, ECS, and EBS to TCM 199 does not improve the nuclear in vitro maturation rate of canine oocytes to the MII stage. c) in dogs, selection of oocytes based on a specific estrous cycle stage should not be used to predict an expected frequency of in vitro meiotic maturation or ability to in vitro embryo development. d) canine oocytes in vitro matured, in vitro fertilized and in vitro cultured are capable of development to 8-cell embryos.

Key words: canine, oocyte, in vitro, maturation, fertilization, cleavage, estrous cycle.

Presented: 12 December 2003

\footnotetext{
**Doctoral Dissertation \# 28 (Field: Biothecnics of Reproduction). 119p. Graduate Program in Veterinary Sciences, Faculdade de Veterinária, Universidade Federal do Rio Grande do Sul (UFRGS), Porto Alegre/Brazil. CORRESPONDENCE: B.A. Rodrigues [berenice@portoweb.com.br].
} 